Abd El-Aziz. S. Fouda*1, Farid I. El-Dossoki², Hamd Abu El-Nadr', Alaa El-Hussein ${ }^{1}$

${ }^{1}$ Mansoura University, Chemistry Department, Faculty of Science, Mansoura-35516, Egypt, ${ }^{2}$ Port-Said University, Chemistry Department, Faculty of Science, Port-Said, Egypt
Scientific paper

ISSN 0351-9465, E-ISSN 2466-2585

UDC:620.198.5:669.587

doi:10.5937/ZasMat1803422F

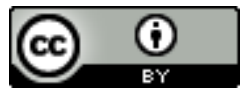

Zastita Materijala 59 (3)

$422-435$ (2018)

\title{
Moringa oleifera plant extract as a copper corrosion inhibitor in binary acid mixture $\left(\mathrm{HNO}_{3}+\mathrm{H}_{3} \mathrm{PO}_{4}\right)$
}

\begin{abstract}
The behavior of $\mathrm{Cu}$ in $1 \mathrm{M}$ mixture of nitric and phosphoric acids containing different concentrations of moringa oleifera leaves (MOL) extract has been studied by weight loss (WL) and electrochemical techniques [potentiodynamic polarization (PP), electrochemical impedance spectroscopy (EIS), and electrochemical frequency modulation (EFM)]. The maximum inhibition efficiency was found to be $89 \%$ at concentration $0.300 \mathrm{~mol} \mathrm{~L}^{-1}$ of the extract at $298 \mathrm{~K}$ after 3 hours immersion period. The inhibition efficiency (IE) increased with increasing the extract concentration while decreased with increasing the temperature indicates that the extract is physically adsorbed on $\mathrm{Cu}$ surface. The adsorption of the extract follows Langmuir adsorption isotherm. Some thermodynamic parameters of activation and adsorption processes were also determined and discussed. Surface analysis was also studied.
\end{abstract}

Keywords: Copper corrosion; $\left(\mathrm{HNO}_{3}+\mathrm{H}_{3} \mathrm{PO}_{4}\right)$, Moringa oleifera leaves extract; EIS, EFM, AFM, SEM.

\section{INTRODUCTION}

Copper and its alloys are widely used materials for their excellent electrical and thermal conductivities in many applications such as electronics and recently in the manufacture of integrated circuits [1-4]. $\mathrm{Cu}$ is relatively noble metal, requiring strong oxidants for its corrosion or dissolution. The most widely used corrosive solution contains nitric acid, so this medium has induced a great deal of research on copper corrosion [5-17]. The present study used a mixture of concentrated nitric acid and phosphoric acid to test the strength and efficiency of the inhibitor and the metal under extremely hard acidic conditions. One of the most important methods in the corrosion protection of $\mathrm{Cu}$ is the use of organic inhibitors. These last decades, researches are reoriented to the application of non-toxic inhibitors called green or eco-friendly environment inhibitors. Natural plants were added in the form of extracts, oil or pure compounds, may play a major role to keep the

\footnotetext{
${ }^{\star}$ Corresponding author: Abd El-Aziz S. Fouda

E-mail: asfouda@hotmail.com,

Paper received: 25. 03. 2018.

Paper accepted: 10. 06. 2018.

Paper is available on the website: www.idk.org.rs/journal
}

environment more healthy, safely and under pollution control. Among the various natural plant extracts products, MOL extract [18] was used as corrosion inhibitor. The use of these natural compounds extracted from plants as corrosion inhibitors have been reported by several authors [19-26].

\section{EXPERIMENTAL METHODS}

\subsection{Materials}

All chemicals were of analytical grade. Cu with $99.8 \%$ purity was used. Approximately $1 \mathrm{~mol} \mathrm{~L}^{-1}$ $\mathrm{HNO}_{3} / \mathrm{H}_{3} \mathrm{PO}_{4}$ mixture was prepared by diluting the appropriate volume of the concentrated chemically pure grade acid $70 \%$ and $85 \%$, with bi-distilled water. The $\mathrm{Cu}$ specimens were rectangular of $(20$ $\mathrm{mm} \times 20 \mathrm{~mm} \times 2 \mathrm{~mm}$ ). A WL method was used to determine the IE based on the $\mathrm{Cu}$ weights in the absence and presence of MOL extract as inhibitor.

\subsection{Preparation of $M O L$ extract}

The present investigation was carried out using the plant namely MOL. The used parts were the leaves of MOL tree. The sample were picked from the trees of Talkha sanitation plant and ground into a fine powder to give $500 \mathrm{~g}$ of powdered materials, a known quantity of the material was soxholated using bi-distilled water. Finally the extract was lyophilized, weighed and preserved at $4^{\circ} \mathrm{C}$ and kept for use when required [27] 


\subsection{Weight Loss (WL) Method}

The $\mathrm{Cu}$ specimens were abraded with successive emery papers, degreased in acetone, rinsed in bi-distilled water and finally dried and weighed. The test pieces were suspended by suitable glass hocks, and under the surface of the test solution by about $1 \mathrm{~cm}$. WL measurements were performed for 3 hours at the temperature range from $25-45^{\circ} \mathrm{C}$. The average $\mathrm{WL}$ at a certain time for each set of the six samples was taken.

\subsection{Electrochemical method}

The electrochemical measurements were performed in a conventional three-electrode electrochemical cell, consisting of platinum electrode, as an auxiliary electrode, saturated calomel electrode (SCE), as the reference and $\mathrm{Cu}$ metal as the working electrode. The working electrode was abraded with emery papers before each measurement. The chemical structures, names, molecular weights and molecular formulas of the main components present in MOL extract are presented below:<smiles>O=c1c(O)c(-c2ccc(O)c(O)c2)oc2cc(O)cc(O)c12</smiles>

Quercetin, $\mathrm{C}_{15} \mathrm{H}_{10} \mathrm{O}_{7}, 302.2357 \mathrm{~g} / \mathrm{mol}$<smiles>O=c1cc(-c2ccc(O)c(O)c2)oc2cc(O)cc(O)c12</smiles>

Luteolin, $\mathrm{C}_{15} \mathrm{H}_{10} \mathrm{O}_{6}, 286.2363 \mathrm{~g} / \mathrm{mol}$

\subsection{Thermodynamic study}

Parameters such as temperature, equilibrium constant $\left(\mathrm{K}_{\mathrm{ads}}\right)$ and change of Gibbs free energy for adsorption $\left(\Delta \mathrm{G}^{\circ}{ }_{\mathrm{ads}}\right)$ are required for thermodynamic investigation. The value of $\Delta G^{\circ}$ ads is an indicator about the type of interaction between inhibitor and metal surface, whether it shows a chemical or physical adsorption. The value of $\mathrm{K}_{\mathrm{ads}}$ obtained from the proposed model of adsorption isotherm can be assumed as the $\mathrm{K}_{\mathrm{ads}}$ required in the thermodynamic study [28]. The thermodynamic expression required to perform the type of adsorption in relation to corrosion inhibition is described as follows:

$$
\Delta G^{\circ}{ }_{a d s}=-R T \ln \left(55.5 K_{a d s}\right)
$$

$\left(\mathrm{R}=8.314 \mathrm{~J} \mathrm{~mol}^{-1} \mathrm{~K}^{-1} ; \mathrm{T}=\right.$ temperature; $55.5=$ concentration of water ( $\mathrm{mol} / \mathrm{L})$ in solution).

\section{RESULTS AND DISCUSSION}

\subsection{Weight loss (WL) method}

Figure1, shows the variation of $\mathrm{WL}$ of $\mathrm{Cu}$ with time in $1 \mathrm{~mol} \mathrm{~L}^{-1} \mathrm{HNO}_{3 /} \mathrm{H}_{3} \mathrm{PO}_{4}$ mixture containing various concentrations of the extract at $289 \mathrm{~K}$. From the plots, it is evident that the $\mathrm{WL}$ of $\mathrm{Cu}$ decreased with the increasing of extract concentration. The degree of surface coverage $(\theta)$ and $(\% \mathrm{IE})$ were calculated using the following equation:

$$
\% I E=\theta \times 100=\left[1-\left(C R_{\text {inh }} / C R_{\text {free }}\right)\right] \times 100
$$

where $\mathrm{CR}_{\text {free }}$ and $C \mathrm{R}_{\text {inh }}$, are the corrosion rates in the absence and in the presence of MOL extract, respectively. It can be seen that the maximum IE of $89 \%$ is achieved at $0.300 \mathrm{~mol} \mathrm{~L}^{-1}$ of extract concentration and \% IE increases with increasing the extract concentration. The (CR) and the (\%IE) at different concentrations of extract for the corrosion of $\mathrm{Cu}$ after $90 \mathrm{~min}$ of immersion in $1 \mathrm{~mol} / \mathrm{L} \quad \mathrm{HNO}_{3} / \mathrm{H}_{3} \mathrm{PO}_{4}$ mixture at $298 \mathrm{~K}$ were presented in Table 1. Arrhenius plots and the activation parameters for extract adsorption on $\mathrm{Cu}$ in $1 \mathrm{~mol} \mathrm{~L}^{-1} \mathrm{HNO}_{3} \mathrm{H}_{3} \mathrm{PO}_{4}$ mixture in absence and presence of various concentrations of $\mathrm{MOL}$ extract were presented in Table 2 and shown in Figures 2 and 3.

Table 1. Corrosion Rate (CR) and inhibition efficiency (\%IE) at different concentrations of extract for the corrosion of $\mathrm{Cu}$ after 90 min of immersion in $1 \mathrm{~mol} / \mathrm{L} \mathrm{HNO} \mathrm{H}_{3} / \mathrm{H}_{3} \mathrm{PO}_{4}$ mixture at $298 \mathrm{~K}$

Tabela 1. Koroziona brzina (CR) i efikasnost inhibicije (\% IE) kod razlicitith koncentracija inhibitora za koroziju bakra posle 90 minuta potapanja u smeši $1 \mathrm{~mol} / \mathrm{L} \mathrm{HNO} / \mathrm{HN}_{3} \mathrm{PO}_{4}$ na $298 \mathrm{~K}$

\begin{tabular}{|c|c|c|}
\hline Conc., $\mathrm{mol} \mathrm{L}^{-1}$ & $\mathrm{CR}, \mathrm{mg} \mathrm{cm}^{-2} \mathrm{~min}^{-1}$ & $\% \mathrm{IE}$ \\
\hline Blank & 0.0242 & -- \\
\hline 0.050 & 0.0106 & 56.3 \\
\hline 0.100 & 0.0076 & 68.4 \\
\hline 0.150 & 0.0074 & 74.1 \\
\hline 0.200 & 0.0049 & 79.8 \\
\hline 0.250 & 0.0041 & 83.1 \\
\hline 0.300 & 0.0026 & 89.3 \\
\hline
\end{tabular}

Table 2. Activation parameters for the adsorption of extract on $\mathrm{Cu}$ in $1 \mathrm{M} \mathrm{HNO} \mathrm{H}_{3} / \mathrm{H}_{3} \mathrm{PO}_{4}$ mixture in absence and presence of various concentrations of extract

Tabela 2. Parametri aktivacije za adsorpciju ekstrakta na $\mathrm{Cu}$ u smeši $1 \mathrm{M} \mathrm{HNO}_{3} / \mathrm{H}_{3} \mathrm{PO}_{4} \mathrm{u}$ odsustvu prisustvu različitih koncentracija ekstrakta

\begin{tabular}{|c|c|c|c|}
\hline $\begin{array}{c}\text { Conc.. } \\
\mathrm{mol} \mathrm{L}^{-1}\end{array}$ & $\begin{array}{c}\mathrm{E}_{\mathrm{a}}{ }^{*}, \mathrm{~kJ} \\
\mathrm{~mol}^{-1}\end{array}$ & $\begin{array}{l}\Delta \mathrm{H}^{*}, \mathrm{~kJ} \\
\mathrm{~mol}^{-1}\end{array}$ & $\begin{array}{c}-\Delta \mathrm{S}^{*}, \mathrm{~J} \mathrm{~mol}^{-1} \\
\mathrm{~K}^{-1}\end{array}$ \\
\hline Blank & 70.5 & 29.5 & 260.6 \\
\hline 0.050 & 88.9 & 37.5 & 262.5 \\
\hline 0.100 & 94.2 & 38.4 & 263.9 \\
\hline 0.150 & 91.0 & 39.8 & 265.7 \\
\hline 0.200 & 103.7 & 43.9 & 266.4 \\
\hline 0.250 & 110.5 & 46.9 & 266.5 \\
\hline 0.300 & 123.5 & 52.5 & 266.6 \\
\hline
\end{tabular}




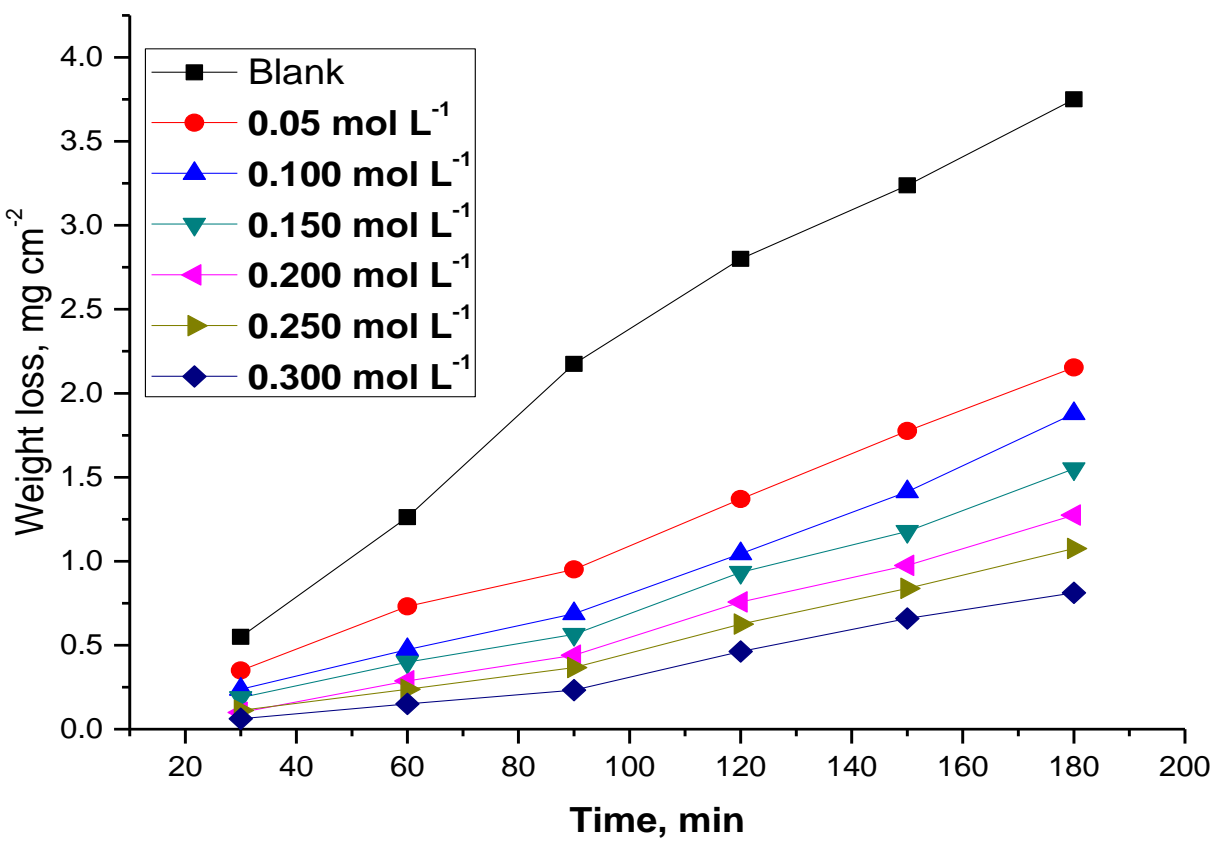

Figure 1. WL-time curves for the corrosion of $\mathrm{Cu}$ in $1 \mathrm{M} \mathrm{HNO}_{3} / \mathrm{H}_{3} \mathrm{PO}_{4}$ mixture in the absence and presence of different concentrations of extract at $298 \mathrm{~K}$

Slika 1. Kriva WL - vreme za koroziju Cu u $1 \mathrm{M} \mathrm{HNO}_{3} / \mathrm{H}_{3} \mathrm{PO}_{4}$ smeši u odsustvu i prisustvu različitih koncentracija ekstrakta biljke na $298 \mathrm{~K}$

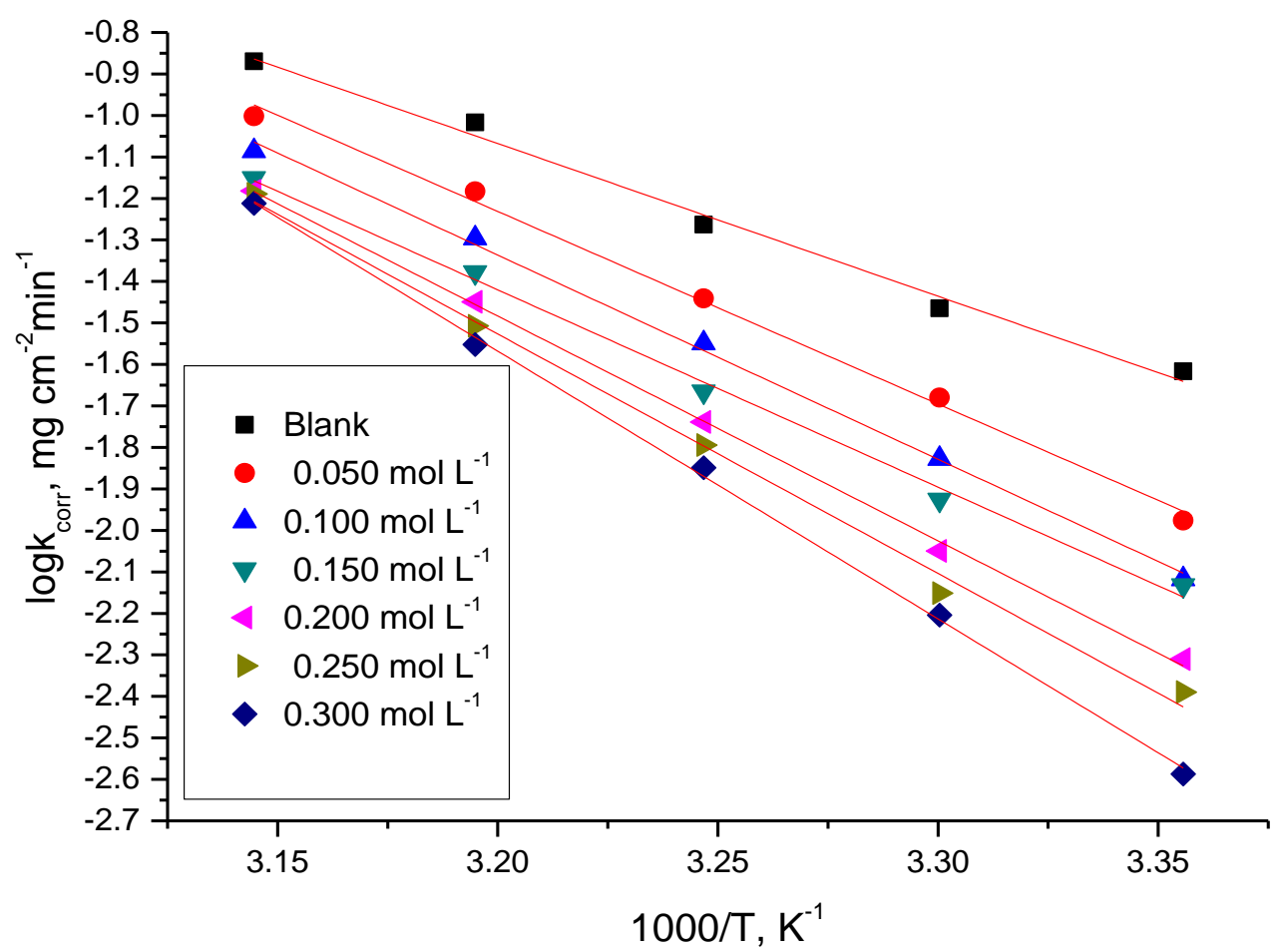

Figure 2. Arrhenius plots for $\mathrm{Cu}$ after 90 minute of immersion in $1 \mathrm{M} \mathrm{HNO} \mathrm{H}_{3} / \mathrm{H}_{3} \mathrm{PO}_{4}$ mixture in the absence and presence of various concentrations of the extract

Slika 2. Arrheniusove krive za Cu nakon 90 minuta uranjanja u smešu $1 \mathrm{M} \mathrm{HNO}_{3} / \mathrm{H}_{3} \mathrm{PO}_{4}$ u odsustvu $\mathrm{i}$ prisustvu različitih koncentracija ekstrakta 


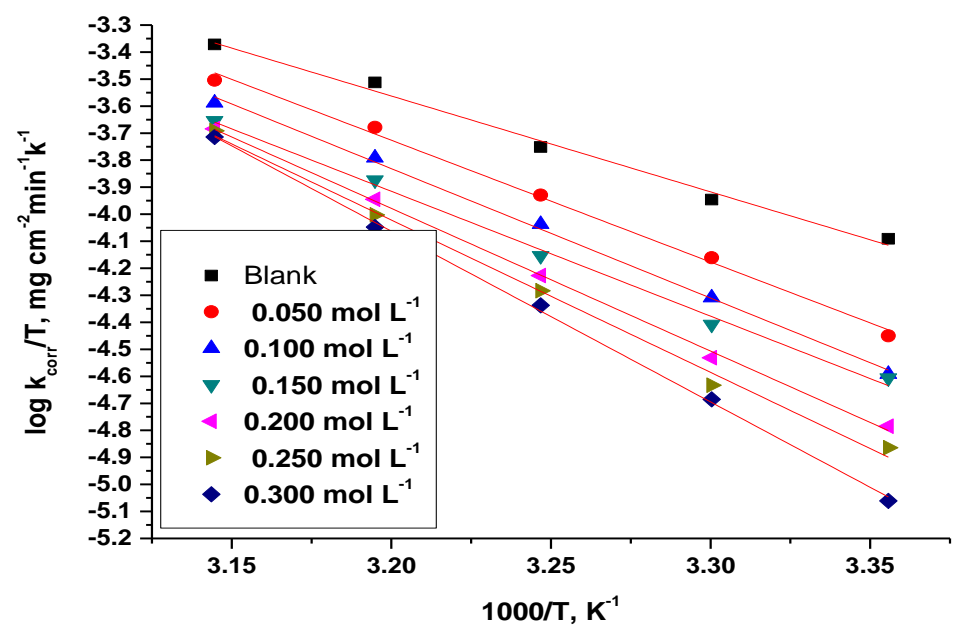

Figure 3. Transition plots for $\mathrm{Cu}$ after 90 minute of immersion in $1 \mathrm{M} \mathrm{HNO}_{3} / \mathrm{H}_{3} \mathrm{PO}_{4}$ mixture in the absence and presence of various concentrations of the extract

Slika 3. Prelazne krive za Cu posle 90 minuta potapanja u smešu $1 \mathrm{M} \mathrm{HNO}_{3} / \mathrm{H}_{3} \mathrm{PO}_{4}$ u odsustvu i prisustvu različitih koncentracija ekstrakta

\subsection{Adsorption isotherms}

Adsorption isotherm values are important to explain the mechanism of corrosion inhibition of organo-electrochemical reactions. The most frequently used isotherm is the Langmuir isotherm (Figure 4):

$$
C / \theta=1 / K_{a d s}+C
$$

Where, $\mathrm{C}$ is the inhibitor concentration in the bulk of the solution, $\theta$ is surface coverage and $\mathrm{K}_{\mathrm{ads}}$ $=1 /$ intercept. $\Delta \mathrm{G}^{\circ}$ ads values at all studied temperatures can be calculated from the following equation:

$$
\Delta G^{\circ}{ }_{a d s}=-R T \ln \left(55.5 K_{a d s}\right)
$$

Where $R$ is the universal gas constant, $T$ is the absolute temperature and 55.5 is molar concentration of water in the solution in $\mathrm{M} / \mathrm{L}$. The heat of adsorption $\left(\Delta \mathrm{H}^{\circ}\right.$ ads $)$ was calculated according to Van't Hoff equation:

$$
\log K_{a d s}=\left(-\Delta H^{\circ}{ }_{\text {ads }} / 2.303 R T\right)+\text { constant (5) }
$$

The values of $\Delta S^{\circ}$ ads can be calculated using the following equation:

$$
\Delta G^{\circ} \text { ads }=\Delta H^{\circ} \text { ads }-T \Delta S^{\circ} \text { ads }
$$

Thermodynamic parameters for the adsorption of extract on $\mathrm{Cu}$ in $1 \mathrm{M} \mathrm{HNO} / \mathrm{H}_{3} \mathrm{PO}_{4}$ mixture at different temperatures were listed in Table 3.

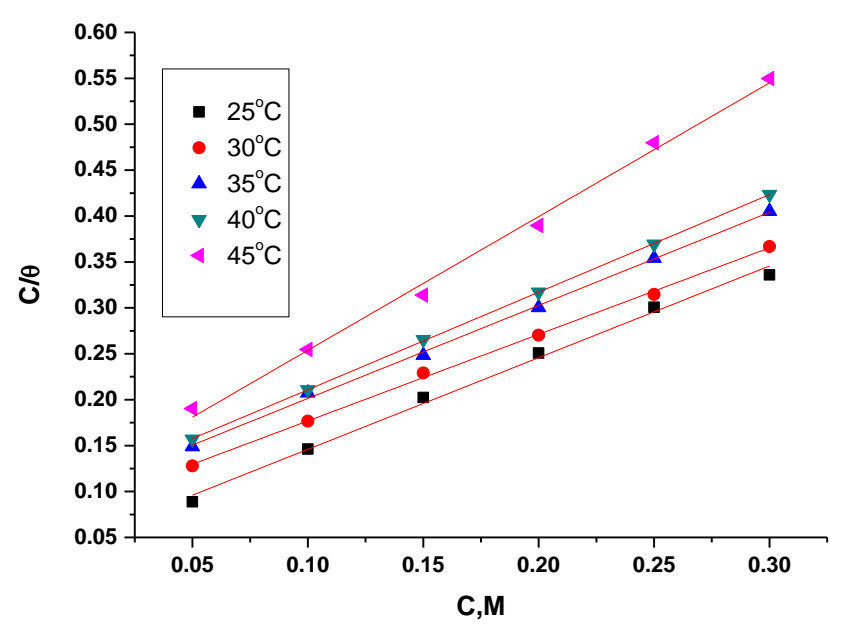

Figure 4. Langmuir adsorption isotherm of the extract on $\mathrm{Cu}$ in $1 \mathrm{M} \mathrm{HNO} \mathrm{H}_{3} / \mathrm{H}_{3} \mathrm{PO}_{4}$ mixture at different temperatures

Slika 4. Langmuirova adsorpcijska izoterma ekstrakta na Cu u smeši $1 \mathrm{M} \mathrm{HNO}_{3} / \mathrm{H}_{3} \mathrm{PO}_{4}$ na različitim temperaturama 
Table 3. Thermodynamic adsorption parameters for the adsorption of the extract on $\mathrm{Cu}$ in $1 \mathrm{M}$ $\mathrm{HNO}_{3} / \mathrm{H}_{3} \mathrm{PO}_{4}$ mixture at different temperatures

Tabela 3. Termodinamički parametri za adsorpciju ekstrakta na $\mathrm{Cu}$ u smeši $1 \mathrm{M} \mathrm{HNO}_{3} / \mathrm{H}_{3} \mathrm{PO}_{4}$ na različitim temperaturama

\begin{tabular}{|c|c|c|c|c|}
\hline $\begin{array}{c}-\Delta \mathrm{S}_{\text {ads, }}^{\circ} \mathrm{J} \\
\mathrm{mol}^{-1} \mathrm{~K}^{-1}\end{array}$ & $\begin{array}{l}-\Delta \mathrm{H}^{\circ} \text { ads, } \\
\mathrm{kJ} \mathrm{mol}^{-1}\end{array}$ & $\begin{array}{l}-\Delta \mathrm{G}^{\circ}{ }_{\text {ads }} \\
\mathrm{kJ} \mathrm{mol}^{-1}\end{array}$ & $\begin{array}{l}\text { Kads, } \\
\mathrm{M}^{-1}\end{array}$ & Temp., \\
\hline 44.9 & \multirow{5}{*}{30.9} & 17.6 & 21.70 & 298 \\
\hline 48.0 & & 16.4 & 12.10 & 303 \\
\hline 47.9 & & 16.2 & 10.00 & 308 \\
\hline 46.6 & & 16.3 & 9.560 & 313 \\
\hline 45.4 & & 16.5 & 9.240 & 318 \\
\hline
\end{tabular}

The negative values of $\Delta \mathrm{G}^{\circ}$ ads reflect that the adsorption of studied extract on $\mathrm{Cu}$ in $1 \mathrm{M}$ $\mathrm{HNO}_{3} / \mathrm{H}_{3} \mathrm{PO}_{4}$ mixture is spontaneous process [29]. $\Delta G^{\circ}$ ads values increase (become less negative) with an increase of temperature which indicates the occurrence of exothermic process due to the extract desorption from the $\mathrm{Cu}$ surface [30]. It is usually accepted that the value of $\Delta \mathrm{G}^{\circ}$ ads around $20 \mathrm{~kJ} \mathrm{~mol}^{-1}$ or lower indicates the electrostatic interaction between charged metal surface and charged organic molecules in the bulk of the solution [31]. The $\Delta \mathrm{H}^{\circ}$ ads value was obtained from the slope of the line in Fig.5. The negative sign of $\Delta \mathrm{H}^{\circ}$ ads reveals that the adsorption of extract molecules is an exothermic process. Generally, an exothermic adsorption process suggests either physisorption or chemisorption while endothermic process is attributed to chemisorptions [32]. Generally, enthalpy values up to $41.9 \mathrm{~kJ} \mathrm{~mol}^{-1}$ are related to the electrostatic interactions between charged molecules and charged metal (physisorption) while those around $100 \mathrm{~kJ} \mathrm{~mol}^{-1}$ or higher are attributed to chemisorption. In the case of investigated extract; the absolute values of enthalpy are relatively low, approaching those typical of physisorption. The value of $\Delta S^{\circ}$ ads in the presence of the investigated extract is large and negative that is accompanied with exothermic adsorption process [33]. The experimental data give good curves fitting for the applied adsorption isotherm as the correlation coefficients $\left(R^{2}\right)$ were in the range $0.950-0.997 . \mathrm{K}_{\text {ads }}$ values decrease with the increase of temperature from 25 to $45^{\circ} \mathrm{C}$.

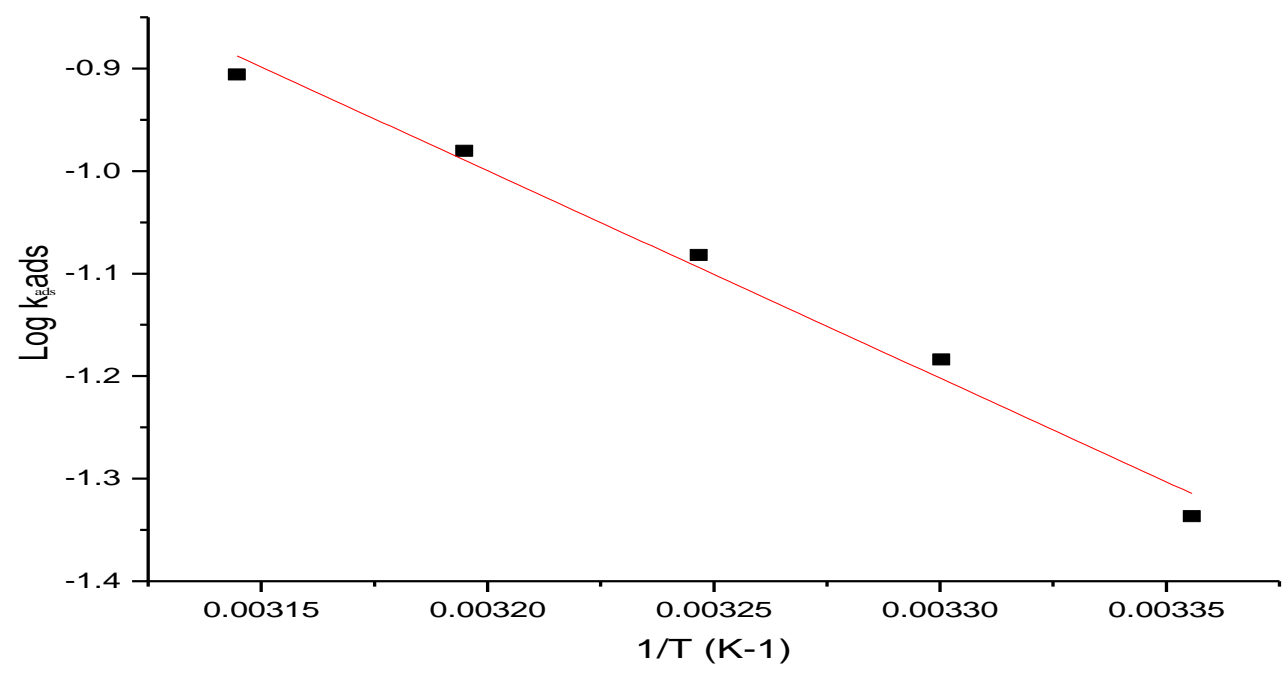

Figure 5. Log $K_{\text {ads }}$ was plotted against $1 / T\left(K^{1}\right)$ for $M O L$ extract Slika 5. Log $K_{\text {ads }}$ je prikazan u odnosu na $1 / T\left(K^{1}\right)$ za MOL ekstrakt

\subsection{Potentiodynamic polarization (PP) measurements}

Polarization measurements were carried out in order to gain knowledge concerning the kinetics of the cathodic and anodic reactions. Figure 6 presents the results of the effect of the extract on the cathodic and anodic polarization curves of $\mathrm{Cu}$ in $1 \mathrm{M} \mathrm{HNO}_{3} / \mathrm{H}_{3} \mathrm{PO}_{4}$ mixture. It could be observed that both the cathodic and anodic reactions were suppressed with the addition of investigated extract, which suggested that extract components reduced anodic dissolution and also retarded the oxygen reduction reaction. Electrochemical corrosion kinetics parameters, i.e. corrosion potential $\left(E_{\text {corr }}\right)$, cathodic and anodic Tafel slopes $\left(\beta_{a}, \beta_{c}\right)$ and corrosion current density ( $\left.i_{\text {corr }}\right)$ obtained from the extrapolation of the polarization curves were given in Table 4 . The values of $\beta_{a}$ and $\beta_{c}$ changed slightly with increasing inhibitor concentration indicated the influence of these compounds in the extract on the kinetics of metal 
dissolution. Due to the presence of some active sites, such as aromatic rings, hetero-atoms in the studied compounds for making adsorption, they may act as adsorption inhibitors. The functional groups and structure of the extract play important roles during the adsorption process. On the other hand, an electron transfer takes place during adsorption of the neutral organic compounds at metal surface [34]. As it can be seen from Table 4, the studied extract reduced both anodic and cathodic currents with a slight shift in corrosion potential $(23.5 \mathrm{mV})$. According to Ferreira and others [35], if the displacement in corrosion potential is more than $85 \mathrm{mV}$ with respect to corrosion potential of the blank solution, the extract can be seen as a cathodic or anodic type. The results obtained from Tafel polarization showed good agreement with the results obtained from WL method. The $(\theta)$ and \% IE were calculated using the following equation:

$$
\% I E=\theta \times 100=\left[1-\left(i_{\text {corr }} / i_{\text {corr }}^{\circ}\right)\right] \times 100
$$

where $\mathrm{i}_{\text {corr }}$ and $\mathrm{i}^{\circ}$ corr are the current densities in presence and absence of extract, respectively.

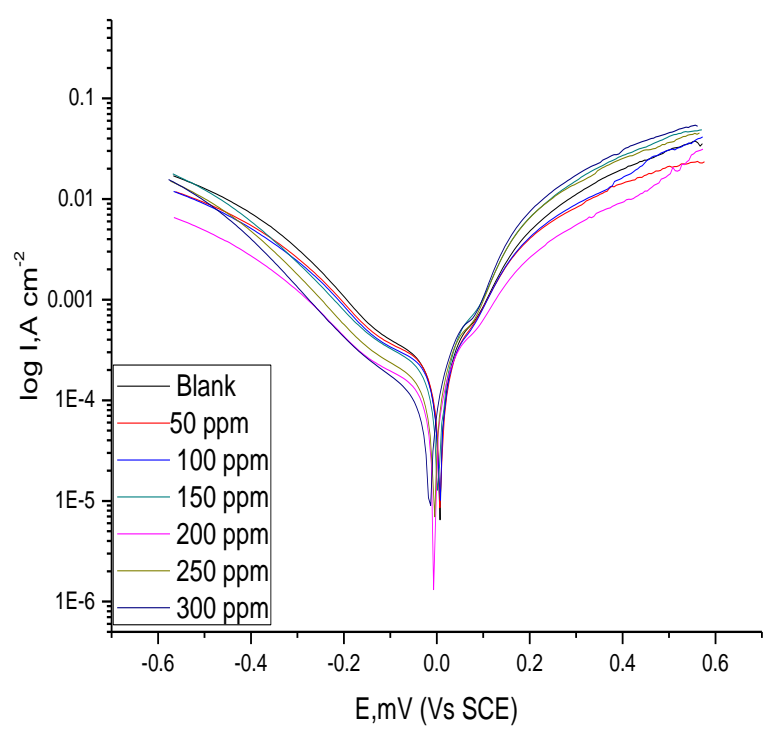

Figure 6. $P P$ curves for the dissolution of $\mathrm{Cu}$ in $1 \mathrm{M}$ $\mathrm{HNO}_{3} / \mathrm{H}_{3} \mathrm{PO}_{4}$ mixture in the absence and presence of different concentrations of extract at $298 \mathrm{~K}$

Slika 6. PP krive za rastvaranje Cu u $1 M$ $\mathrm{HNO}_{3} / \mathrm{H}_{3} \mathrm{PO}_{4}$ smeši u odsustvu i prisustvu različitih koncentracija ekstrakta na $298 \mathrm{~K}$

Table 4. Effect of concentrations of extract on the $\left(E_{\text {corr }}\right)$, ( $\left.i_{\text {corr }}\right),\left(\beta_{c}, \beta_{a}\right),\left(k_{\text {corr }}\right),(\theta)$, and (\%IE) of $\mathrm{Cu}$ in $1 M$ $\mathrm{HNO}_{3} / \mathrm{H}_{3} \mathrm{PO}_{4}$ mixture at $298 \mathrm{~K}$

Tabela 4. Uticaj koncentracija ekstrakta na ( $\left.E_{\text {corr }}\right)$, $\left(i_{c o r r}\right),\left(\beta_{c}, \beta_{a}\right)$, $\left(k_{\text {corr }}\right),(\theta)$, i (\% IE) Cu u smeši $1 M \mathrm{HNO}_{3} / \mathrm{H}_{3} \mathrm{PO}_{4}$ na $298 \mathrm{~K}$

\begin{tabular}{|c|c|c|c|c|c|c|c|}
\hline $\begin{array}{c}\text { Conc } \\
\mathrm{mol} \mathrm{L}^{-1}\end{array}$ & $\begin{array}{c}\mathrm{i}_{\text {corr }} \\
\mu \mathrm{Am}^{-2}\end{array}$ & $\begin{array}{c}\mathrm{E}_{\text {corr }} \\
\mathrm{mV} \text { vs SCE }\end{array}$ & $\begin{array}{c}\beta_{\mathrm{a}}, \\
\mathrm{mV} \mathrm{dec}^{-1}\end{array}$ & $\begin{array}{c}-\beta_{\mathrm{c}}, \\
\mathrm{mV} \mathrm{dec}^{-1}\end{array}$ & $\begin{array}{c}\mathrm{CR}, \\
\mathrm{mmy}^{-1}\end{array}$ & $\theta$ & $\% \mathrm{IE}$ \\
\hline Blank & 271.0 & +0.5 & 610 & 400 & 138.6 & --- & --- \\
\hline 0.050 & 104.0 & +3.9 & 111 & 466 & 50.16 & 0.616 & 61.6 \\
\hline 0.100 & 102.0 & -4.2 & 102 & 479 & 48.89 & 0.624 & 62.4 \\
\hline 0.150 & 91.0 & -10.0 & 109 & 481 & 41.50 & 0.664 & 66.4 \\
\hline 0.200 & 85.7 & -12.0 & 111 & 481 & 40.27 & 0.683 & 68.3 \\
\hline 0.250 & 84.1 & -22.0 & 99 & 417 & 38.28 & 0.689 & 68.9 \\
\hline 0.300 & 78.8 & -24.0 & 92 & 418 & 35.70 & 0.709 & 70.9 \\
\hline
\end{tabular}

\subsection{Electrochemical impedance spectroscopy} (EIS) measurements

Nyquist plots of $\mathrm{Cu}$ in uninhibited and inhibited acid solutions containing different concentrations of the extract are presented in Figure 7a. EIS spectra obtained consists of one depressed capacitive loop (one time constant in Bode-phase plot (Figure 7b)). The increased diameter of capacitive loop obtained in $1 \mathrm{M} \mathrm{HNO}_{3} / \mathrm{H}_{3} \mathrm{PO}_{4}$ mixture in presence of extract indicated the inhibition of corrosion $\mathrm{Cu}$. The high frequency capacitive loop may be attributed to the charge transfer reaction. Corrosion kinetic parameters derived from EIS measurements and inhibition efficiencies are given in Table 5. Double layer capacitance $\left(C_{\mathrm{dl}}\right)$ and charge transfer resistance $\left(R_{\mathrm{ct}}\right)$ were obtained from EIS measurements as described elsewhere [36]. It is apparent from Table 5 that the impedance of the inhibited system amplified with the inhibitor the $C_{\mathrm{dl}}$ values decreased with inhibitor. This decrease in $C_{\mathrm{dl}}$ results from a decrease in local dielectric constant and/or an increase in the thickness of the double layer, suggested that extract molecules inhibit the $\mathrm{Cu}$ corrosion by adsorption at the metal/acid interface [37]. The depression in Nyquist semicircles is a feature for solid electrodes and often referred to as frequency dispersion and attributed to the roughness and other in homogeneities of the solid electrode [38]. 


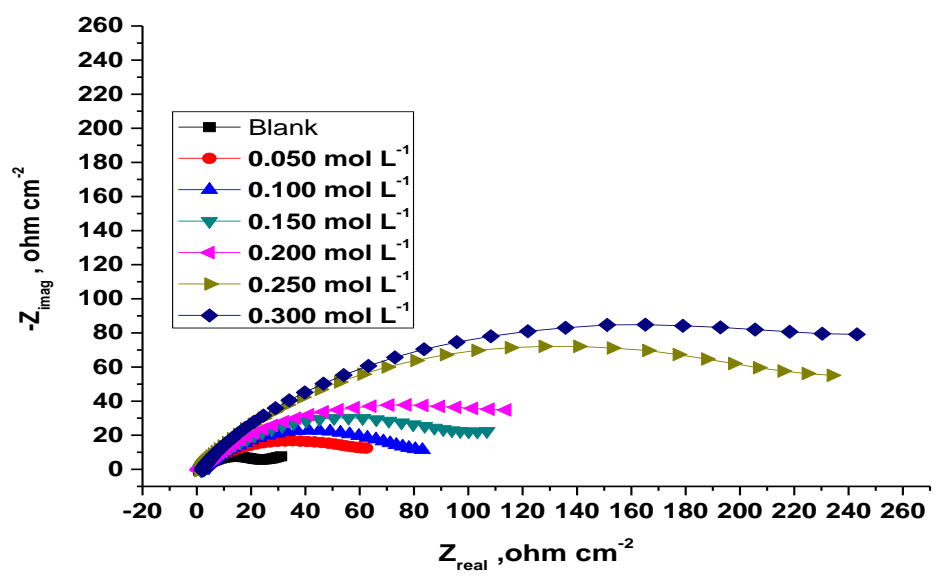

Figure 7a. The Nyquist plots for the corrosion of $\mathrm{Cu}$ in $1 \mathrm{M} \mathrm{HNO}_{3} / \mathrm{H}_{3} \mathrm{PO}_{4}$ mixture in the absence and presence of different concentrations of extract at $298 \mathrm{~K}$

Slika 7a. Nyquist-ove krive za koroziju Cu u smeši $1 \mathrm{M} \mathrm{HNO}_{3} / \mathrm{H}_{3} \mathrm{PO}_{4}$ u odsustvu i prisustvu različitih koncentracija ekstrakta na $298 \mathrm{~K}$

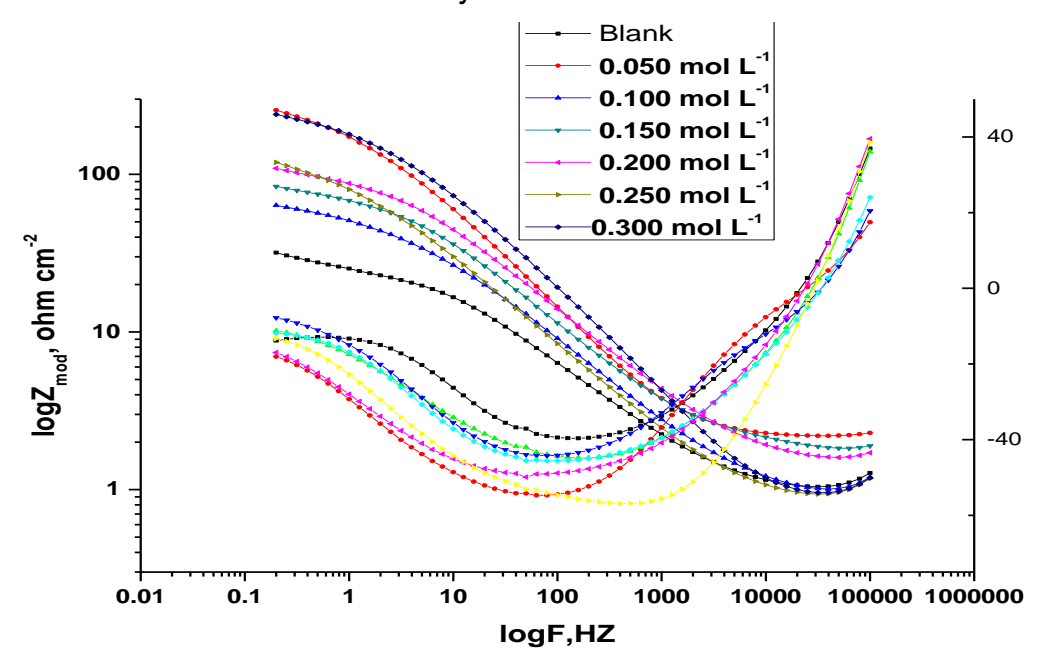

Figure 7b. The Bode plots for corrosion of $\mathrm{Cu}$ in $1 \mathrm{M} \mathrm{HNO} \mathrm{HN}_{3} / \mathrm{H}_{3} \mathrm{PO}_{4}$ mixture in the absence and presence of different concentrations of extract at $298 \mathrm{~K}$

Slika 7b. Bode-ove krive za koroziju $\mathrm{Cu}$ u smeši $1 \mathrm{M} \mathrm{HNO}_{3} / \mathrm{H}_{3} \mathrm{PO}_{4}$ u odsustvu i prisustvu različitih koncentracija ekstrakta na $298 \mathrm{~K}$

Table 5. The EIS parameters for the corrosion of $\mathrm{Cu}$ in $1 \mathrm{M} \mathrm{HNO} / \mathrm{H}_{3} \mathrm{PO}_{4}$ mixture, in the absence and in the presence of different concentrations of extract at $298 \mathrm{~K}$

Tabela 5. Parametri EIS za koroziju $\mathrm{Cu}$ u smeši $1 \mathrm{M} \mathrm{HNO}_{3} / \mathrm{H}_{3} \mathrm{PO}_{4}$, u odsustvu $i$ u prisustvu različitih koncentracija ekstrakta na $298 \mathrm{~K}$

\begin{tabular}{|c|c|c|c|c|}
\hline Conc., $\mathrm{mol} \mathrm{L}^{-1}$ & $\mathrm{R}_{\mathrm{ct}}, \Omega \mathrm{cm}^{2}$ & $\mathrm{C}_{\mathrm{dl}} \times 10^{4}, \mathrm{~F} \mathrm{~cm}^{-2}$ & $\theta$ & \% IE EIS \\
\hline Blank & 28.75 & 6.1149 & ---- & 55.0 \\
\hline 0.050 & 63.85 & 5.8140 & 0.550 & 65.9 \\
\hline 0.100 & 84.20 & 4.464 & 0.659 & 74.5 \\
\hline 0.150 & 112.70 & 4.330 & 0.745 & 78.6 \\
\hline 0.200 & 134.10 & 3.835 & 0.786 & 87.6 \\
\hline 0.250 & 231.80 & 3.208 & 0.876 & 89.4 \\
\hline 0.300 & 272.00 & 2.4083 & 0.894 & 8 \\
\hline
\end{tabular}

In this behaviour of solid electrodes, the parallel network: charge transfer resistance-double layer capacitance is established where an inhibitor in present. For the description of a frequency 
independent phase shift between an applied ac potential and its current response, a constant phase element (CPE) is used, which is defined in impedance representation as in the following equation:

$$
Z_{C P E}=Y_{o}^{-1}(i \omega)^{-n}
$$

Where, $Y_{0}$ is the CPE constant, $\omega$ is the angular frequency (in rad $\mathrm{s}^{-1}$ ), $\mathrm{i}^{2}=-1$ is the imaginary number and $n$ is a CPE exponent which can be used as a gauge of the heterogeneity or roughness of the surface [39]. Depending on the value of $n$, CPE can represent resistance $\left(n=0, Y_{0}=R\right)$, capacitance $\left(n=1, Y_{0}=C\right)$, inductance $\left(n=-1, Y_{0}=\right.$ L) or Warburg impedance $\left(n=0.5, Y_{0}=W\right)$. Figure 8 showed the electrical equivalent circuit employed to analyze the impedance spectra. Excellent fit with this model was obtained for all experimental data. The $(\theta)$ and \% IE were calculated using the following equation:

$$
\% I E=\theta \times 100=\left[1-\left(R_{c t} / R_{c t^{\circ} \text { corr }}\right)\right] \times 100
$$

where $R_{c t}$ and $R_{\mathrm{ct}^{\circ}}$ are the charge transfer resistances in absence and presence of extract, respectively.

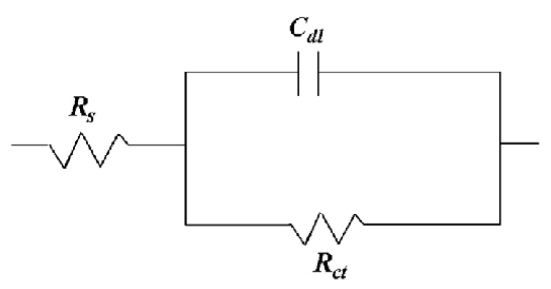

Figure 8: Equivalent circuit used to model impedance data

Slika 8: Ekvivalentno kolo koje se koristi za dobijanje modela impedanse
The results obtained from WL, PP and EIS techniques are in a good agreement but it is of interest to note that, the values of \% IE given by electrochemical techniques are higher than those obtained by WL measurements; this may be due to the fact that the electrochemical measurements were carried out on freshly prepared solutions and are time independant.

\subsection{Electrochemical frequency modulation (EFM) measurements}

EFM is a non-destructive corrosion measurement like EIS; it is a small signal ac technique. Unlike EIS, however, two sine waves (at different frequencies) are applied to the cell simultaneously. The great strength of the EFM is the causality factors which serve as an internal check on the validity of the EFM measurement [40]. The results of EFM experiments are a spectrum of current response as a function of frequency. The spectrum is called the intermodulation spectrum. The spectra contain current responses assigned for harmonical and intermodulation current peaks. The larger peaks (Figure 9) were used to calculate the corrosion current. The inhibition efficiencies, \% IE increase with increasing the studied extract concentrations. Corrosion kinetic parameters, namely corrosion current density ( $\mathrm{i}_{\text {corr }}$, Tafel constants $\left(\beta_{\mathrm{a}}, \beta_{\mathrm{c}}\right)$ and casualty factors (CF-2, CF-3) were listed Table 6 as a function of concentration of the extract at $298 \mathrm{~K}$. The causality factors in Table 6 , which are very close to theoretical values according to the EFM theory, should guarantee the validity of Tafel slopes and corrosion current densities. The standard values for CF-2 and CF-3 are 2.0 and 3.0 , respectively [41].

Table 6. Electrochemical kinetic parameters obtained from EFM technique for Cu corrosion in $1 \mathrm{M} \mathrm{HNO} / \mathrm{H}_{3} \mathrm{PO}_{4}$ mixture in the absence and Presence of different concentrations of investigated extract at $298 \mathrm{~K}$

Tabela 6. Elektrohemijski kinetički parametri dobijeni iz EFM tehnike za Cu koroziju u $1 \mathrm{M} \mathrm{HNO}_{3} / \mathrm{H}_{3} \mathrm{PO}_{4}$ smeši u odsustvu i prisustvo različitih koncentracija ekstrakta na $298 \mathrm{~K}$

\begin{tabular}{|c|c|c|c|c|c|c|c|c|}
\hline$\theta$ & IE\% & C.R, mpy & CF-3 & CF-2 & $\beta_{\mathrm{a}, \mathrm{mV} \mathrm{dec}^{-1}}$ & $\mathrm{Bc}, \mathrm{mV} \mathrm{dec}^{-1}$ & Icorr, $\mu \mathrm{A} \mathrm{cm}$ & Conc., $^{-2} \mathrm{~mol} \mathrm{~L}^{-1}$ \\
\hline--- & --- & 84.43 & 1.9 & 1.95 & 200 & 190 & 171.1 & Blank \\
\hline 0.523 & 52.3 & 40.26 & 2.5 & 1.90 & 225 & 183 & 81.59 & 0.050 \\
\hline 0.653 & 65.3 & 29.29 & 3.2 & 2.00 & 172 & 119 & 59.36 & 0.100 \\
\hline 0.500 & 50.0 & 28.28 & 3.3 & 2.00 & 174 & 98 & 58.47 & 0.150 \\
\hline 0.702 & 70.2 & 25.13 & 3.2 & 1.99 & 142 & 86 & 50.93 & 0.200 \\
\hline 0.734 & 73.4 & 22.48 & 3.5 & 1.90 & 215 & 82 & 45.55 & 0.250 \\
\hline 0.790 & 79.0 & 17.76 & 3.0 & 2.019 & 283 & 80 & 35.98 & 0.300 \\
\hline
\end{tabular}



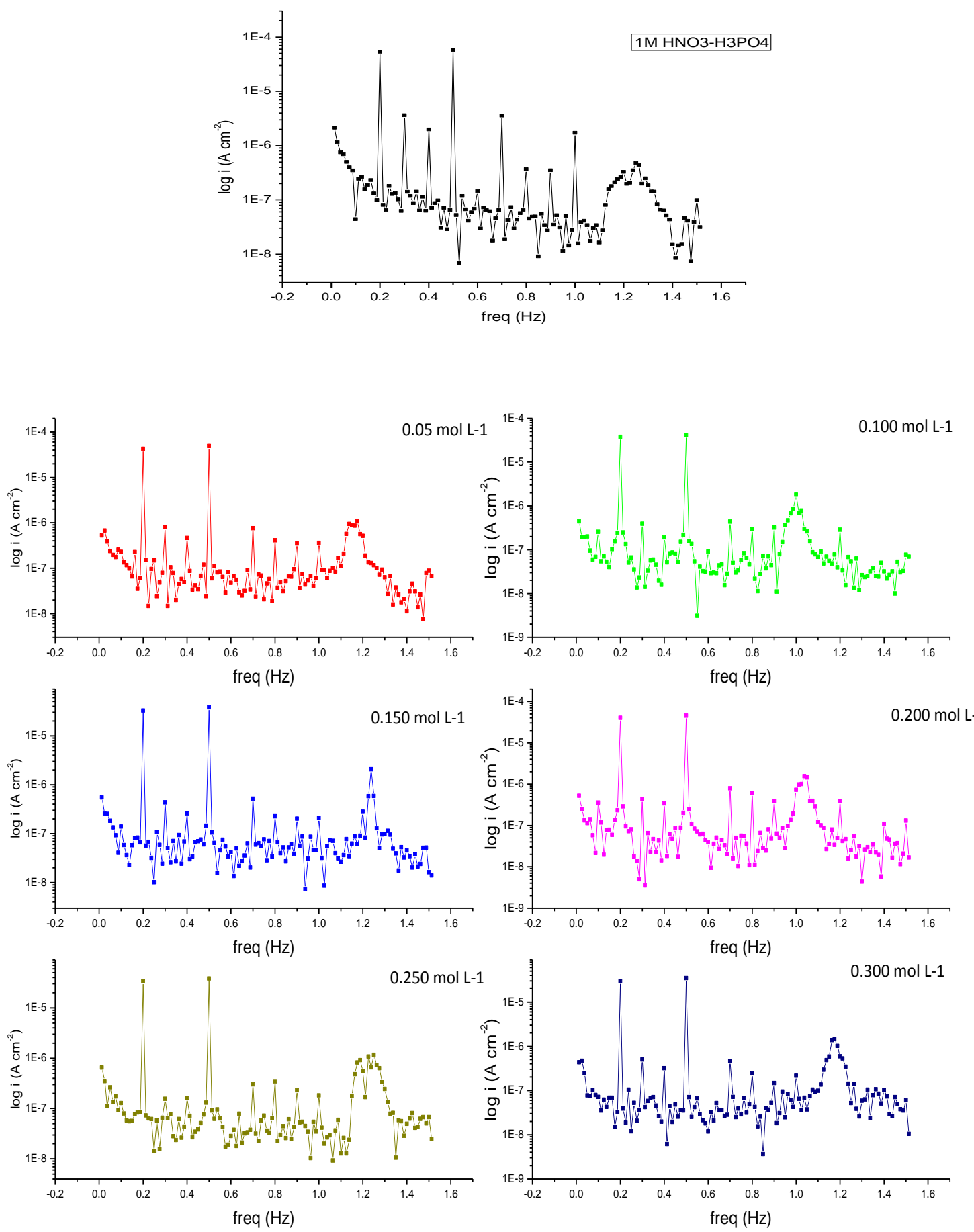

Figure 9. EFM intermodulation spectra of $\mathrm{Cu}$ in $1 \mathrm{M} \mathrm{HNO}_{3} / \mathrm{H}_{3} \mathrm{PO}_{4}$ mixture for extract at $298 \mathrm{~K}$ Slika 9. EFM intermodulacijski spektri Cu u $1 \mathrm{M} \mathrm{HNO}_{3} / \mathrm{H}_{3} \mathrm{PO}_{4}$ za ekstrakt na $298 \mathrm{~K}$

\subsection{Surface Analysis [scanning electron microscopy (SEM) studies]}

A photograph of the polished $\mathrm{Cu}$ surface before immersion in $1 \mathrm{M} \mathrm{HNO} / \mathrm{H}_{3} \mathrm{PO}_{4}$ mixture solution is shown in Figure 10. The photograph shows the surface was smooth and without pits. A photograph of the $\mathrm{Cu}$ surface after immersion in $1 \mathrm{M}$ $\mathrm{HNO}_{3} / \mathrm{H}_{3} \mathrm{PO}_{4}$ mixture solution is shown in Figure 11. The photograph revealed that, the surface was strongly damaged in the absence of MOL extract. A photograph of the $\mathrm{Cu}$ surface after immersion in $1 \mathrm{M} \mathrm{HNO} / \mathrm{H}_{3} \mathrm{PO}_{4}$ mixture solution containing 0.300 
$\mathrm{molL}^{-1}$ of extract is shown in Figure 12. It was found that the damage observed in figures disappeared and the surface was free from pits and it was smooth. It can be concluded from Figure 12 that corrosion decreased largely in the presence of extract hence corrosion was inhibited strongly when extract was present in the medium. In the presence $0.300 \mathrm{~mol} \mathrm{~L}^{-1}$ of extract, there is much less damage on the $\mathrm{Cu}$ surface, which further confirm the inhibit ion action. Also, there is an adsorbed film adsorbed on $\mathrm{Cu}$ surface .In accordance, it might be concluded that the adsorption film can efficiently inhibits the corrosion of Cu.

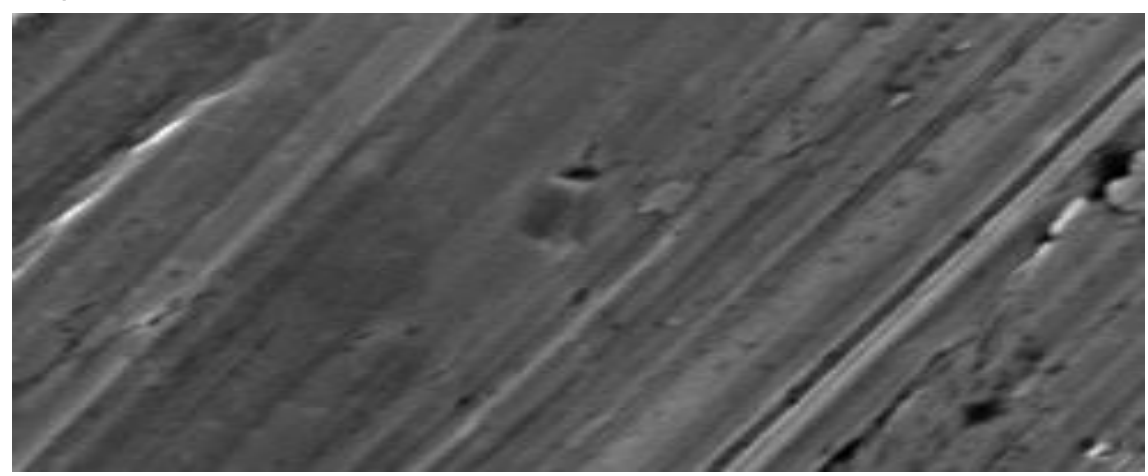

Figure 10. SEM micrographs of Cu surface before of immersion in $1 \mathrm{M} \mathrm{HNO}_{3} / \mathrm{H}_{3} \mathrm{PO}_{4}$ mixture solution

Slika 10. SEM mikrografija površine bakra pre potapanja u $1 \mathrm{M}$ rastvor smeše $\mathrm{HNO}_{3} / \mathrm{H}_{3} \mathrm{PO}_{4}$

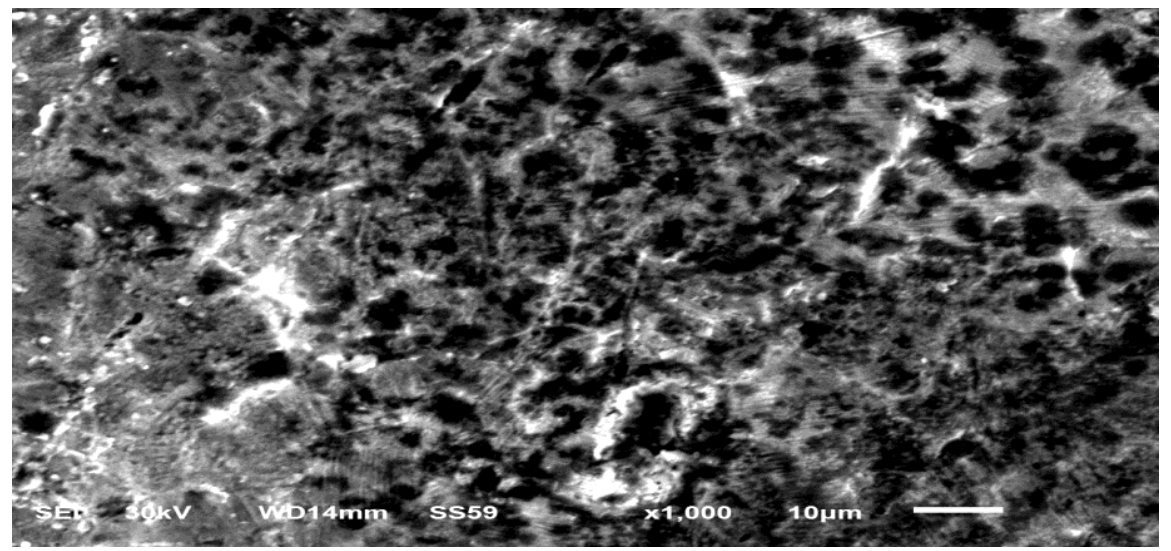

Figure 11. SEM micrographs of Cu surface after $10 \mathrm{~h}$ of immersion in $1 \mathrm{M} \mathrm{HNO}_{3} / \mathrm{H}_{3} \mathrm{PO}_{4}$ mixture

Slika 11. SEM mikrografija Cu površine nakon $10 \mathrm{~h}$ potapanja u smešu $1 \mathrm{M} \mathrm{HNO} \mathrm{H}_{3} / \mathrm{H}_{3} \mathrm{PO}_{4}$

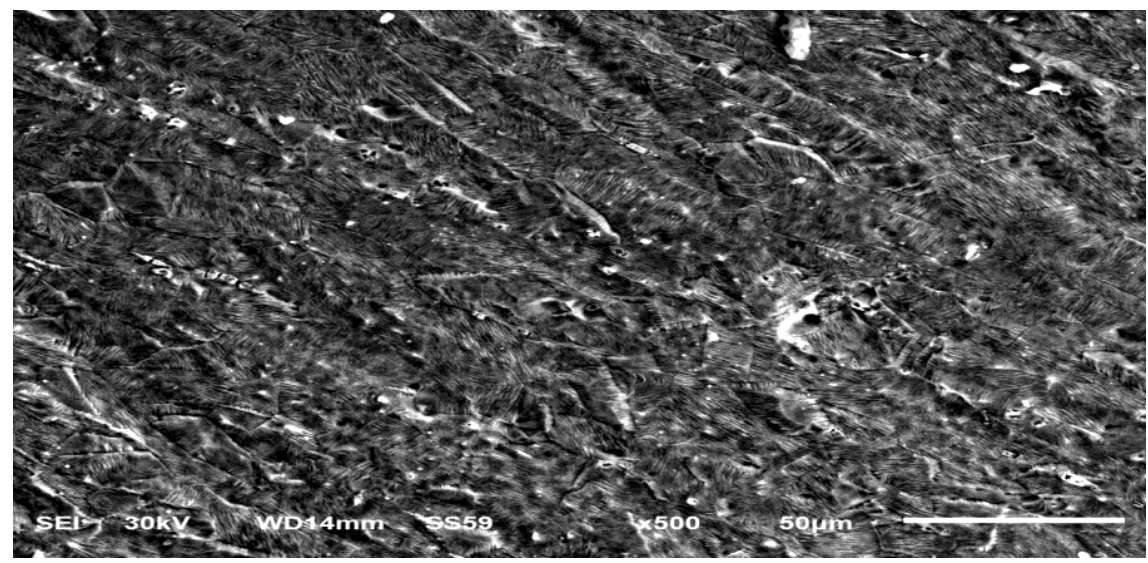

Figure 12. SEM micrographs of Cu surface after $10 \mathrm{~h}$ of immersion in $1 \mathrm{M} \mathrm{HNO}_{3} / \mathrm{H}_{3} \mathrm{PO}_{4}$ mixture $+0.300 \mathrm{~mol} \mathrm{L^{-1 }}$ of $\mathrm{MOL}$ extract at $25^{\circ} \mathrm{C}$

Slika 12. SEM mikrografija Cu površine nakon $10 \mathrm{~h}$ potapanja u smešu $1 \mathrm{M} \mathrm{HNO}_{3} / \mathrm{H}_{3} \mathrm{PO}_{4}+0,300 \mathrm{~mol} \mathrm{~L}^{-1}$ ekstrakta $\mathrm{MOL}$-a na $25^{\circ} \mathrm{C}$ 


\section{Atomic force microscopy characterization}

AFM technique supplies photos with atomic or near-atomic-resolution surface topography which able to giving the surface roughness of coupons by the angstrom-scale. Atomic force microscopy (AFM) is a very higher resolution type of scanning probe microscopy on the order of fractions of a nanometer, more than 1000 times better than the optical diffraction limit [42]. Fig.(13a) shows the three dimensional (3D) AFM morphologies for polished Cu surface as standard sample, Fig.(13b) shows surface immersed in $1 \mathrm{M} \mathrm{HNO}_{3} / \mathrm{H}_{3} \mathrm{PO}_{4}$ as blank sample and Fig.(13c) Cu surface immersed in $1 \mathrm{M} \mathrm{HNO}_{3} / \mathrm{H}_{3} \mathrm{PO}_{4}+0.300 \mathrm{~mol} \mathrm{~L}{ }^{-1}$ of $\mathrm{MOL}$ extract. AFM image analysis was carried out to obtain the roughness average (Sa), the root mean average $(\mathrm{Sq})$ and the peak height (Sp) for the polished $\mathrm{Cu}$ (free sample), copper surface immersed in $1 \mathrm{M}$ $\mathrm{HNO}_{3} / \mathrm{H}_{3} \mathrm{PO}_{4}$ ( blank sample) and $\mathrm{Cu}$ surface immersed in $1 \mathrm{M} \mathrm{HNO}_{3} / \mathrm{H}_{3} \mathrm{PO}_{4}+0.300 \mathrm{~mol} \mathrm{~L}^{-1}$ of MOL extract. The obtained data from AFM analysis were listed in Table 7

Table 7. AFM data for Cu surface with and without $0.300 \mathrm{~mol} \mathrm{~L}^{-1}$ extract

Tabela 7. AFM podaci za Cu površinu sa i bez 0.300 mol $L^{-1}$ ekstrakta

\begin{tabular}{|c|c|c|c|}
\hline Sample & Sa & Sq & Sp \\
\hline Free & 21.18 & 25.34 & 40.51 \\
\hline Blank & 697.2 & 809.72 & 1845.6 \\
\hline MOL extract & 113.27 & 153.32 & 520.11 \\
\hline
\end{tabular}

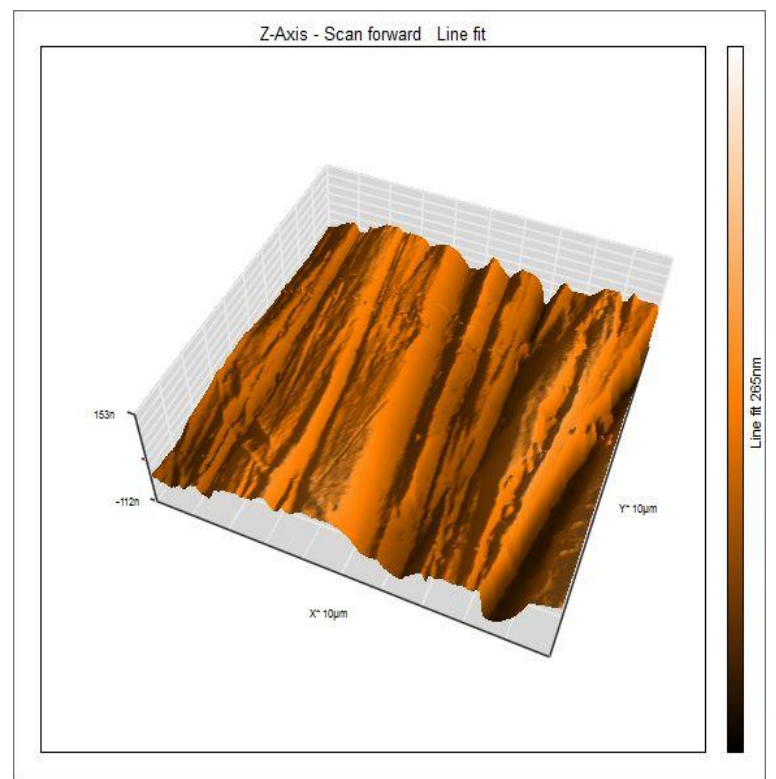

a) Free $\mathrm{Cu}$ - Slobodan $\mathrm{Cu}$

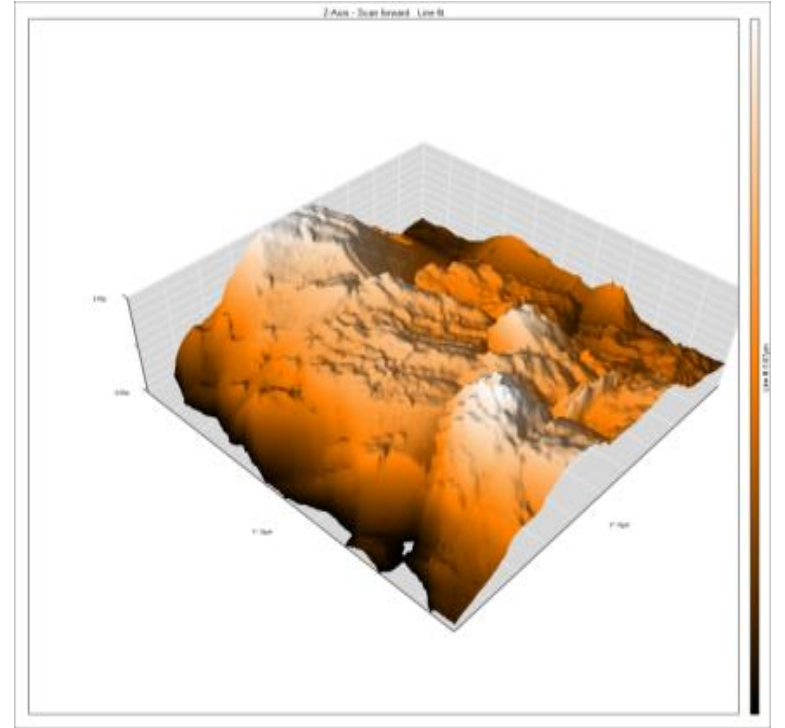

b) blank - prazan

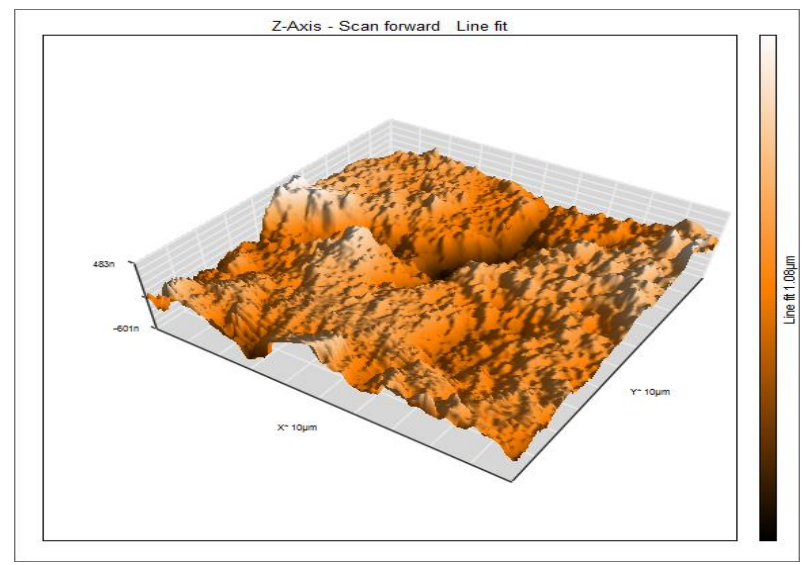

c) $0.300 \mathrm{~mol} \mathrm{~L}^{-1} \mathrm{MOL}$ extract

Fig.13. Three dimensional (3D) AFM morphologies for polished $\mathrm{Cu}$ (a), blank (b) and in presence of $0.300 \mathrm{~mol} \mathrm{~L}^{-1}$ extract (c)

Slika 13. Trodimenzionalne (3D) AFM morfologije za polirani Cu (a), prazan (b) i u prisustvu ekstrakta $0,300 \mathrm{~mol} \mathrm{~L}^{-1}$ (c)

\section{Mechanism of corrosion inhibition}

Generally, it is assumed that the first stage in the action mechanism of the inhibition in acid medium is the adsorption of the inhibitor onto the metal surface. The process of adsorption is influenced by the nature and the charge of the metal, by the chemical structure of the organic inhibitor and the type of aggressive electrolyte. The charge of the metal surface can be determined from the potential of zero charge [43]. The $\mathrm{Cu}$ surface is positively charged in $1 \mathrm{M}$ acidic solution. There is a tendency of the acid anions $\left(\mathrm{NO}_{3}{ }^{-}\right.$or $\mathrm{PO}_{4}{ }^{3-}$ ions) to be specifically adsorbed creating an excess negative charge towards the solution and 
favor more adsorption of the protonated components [44]. The adsorption of extract components on $\mathrm{Cu}$ surface by following ways: (i) electrostatic interaction of protonated component molecules with preadsorbed $\mathrm{NO}_{3}^{-}$or $\mathrm{PO}_{4}^{3-}$ ions (physisorption) (ii) interaction between unshared electron pairs of hetero-atoms $(\mathrm{N}, \mathrm{O}, \mathrm{S})$ and vacant $\mathrm{d}$-orbital of Cu-atoms (chemisorption) and (iii) donor-acceptor interactions between the $\pi$ electrons of aromatic ring and vacant d-orbital of Cu-atoms. The protonated sites of extract molecules may adsorb on the metal surface through a synergistic effect with pre-adsorbed $\mathrm{NO}_{3}{ }^{-}$ or $\mathrm{PO}_{4}{ }^{3-}$. The accumulation of extra negative charges on the $\mathrm{Cu}$ surface can be transferred from the $\mathrm{d}$ orbital of $\mathrm{Cu}$ to unoccupied $\pi *$ (anti-bonding) of extract molecules (retro-donation). The combination of all ways of adsorption strengthens adsorption of extract molecules on Cu surface [45]. Finally, a layer of adsorbed extract film is formed on the Cu surface and acts as a barrier between the metal and corrosive medium, to prevent the corrosion of metal. On the basis of the above analysis and speculation, one can conclude that the studied extract is of mixed-type inhibitor, and the adsorption of the extract contains two modes of interaction, i.e. physisorption and chemisorption

\section{CONCLUSIONS}

The investigated extract (MOL) is considered a good corrosion inhibitor for $\mathrm{Cu}$. The inhibiting action of this extract was increased with increasing the extract concentration while it decreased with increasing temperature. The \% IE of this extract reached $89 \%$ at $0.300 \mathrm{~mol} \mathrm{~L}^{-1}$. The extract was adsorbed physically and spontaneously on copper surface following Langmuir adsorption isotherm. The charge transfer resistance $\left(R_{\mathrm{ct}}\right)$ increased whiles the capacitance double layer $\left(\mathrm{C}_{\mathrm{dl}}\right)$ decreased by increasing the extract concentration. The surface analysis indicated the formation of protective film on the copper surface. Reasonably, good agreement was observed between the results obtained by both the WL and electrochemical measurements.

\section{REFERENCES}

[1] V.Oteino-Alergo, N.Huynh, T.Notoya, S.E.Bottle, D.P.Schwcinsberg (1999) Inhibitive effect of 4- and 5-carboxybenzotriazole on copper corrosion in acidic sulphate and hydrogen sulphide solutions, Corros. Sci., 41(4, 1), 685-697.

[2] H.Y.Tsai, S.C.Sun, S.J.Wang (2000) Characterization of Sputtered Tantalum Carbide
Barrier Layer for Copper Metallization, J. Electrochem. Soc., 147, 2766-2772.

[3] A.Krishnamoorthy, K.Chanda, S.P.Murarka, G. Ramanath, J.G.Ryan (2001) Self-assembled nearzero-thickness molecular layers as diffusion barriers for Cu metallization, Appl. Phys. Lett., 78(17), 2467-2469.

[4] C.E.Ho, W.T.Chen, C.R.Kao (2001)Interactions between solder and metallization during long-term aging of advanced microelectronic packages, J. of Electronic Mat., 30(4), 379-385.

[5] U.R.Evans (1944) Behaviour of metals in nitric acid. Trans, Farad Soc., 40, 120-130.

[6] J.Abdul Nasser, V.Rethinagiri , J. Abdul Hakeem (2012) Investigation of the inhibition of copper corrosion in nitric acid solutions by organic sulphide compound, Adv.Appl. Sci. Res., 3(3), 1749-1756.

[7] A.S.Fouda, K.Shalabi, A.A.Idress (2015) Ceratonia siliqua extract as a green corrosion inhibitor for copper and brass in nitric acid solutions, Green Chemistry Letters and Reviews, 8(3-4), 17-29.

[8] A.Zarrouk, A.Dafali, B.Hammouti, H.Zarrok, S.Boukhris, M.Zertoubi (2010) Comparative Study of new Pyridazine Derivatives Towards Corrosion of Copper in Nitric Acid, Int. J. Electrochem. Sci., 5, 696-705.

[9] A.Zarrouk, I. Warad, B. Hammouti, A Dafali, S.S. AlDeyab, N. Benchat (2010) The Effect of Temperature on the Corrosion of $\mathrm{Cu} / \mathrm{HNO} 3$ in the Presence of Organic Inhibitor, Int. J. Electrochem. Sci., 5, 1516-1526.

[10] A.Zarrouk, B. Hammouti, A. Dafali, H. Zarrok (2011) L-Cysteine methyl ester hydrochloride: A new corrosion inhibitor for copper in nitric acid. Der Pharma Chemica, 3(4), 266-274.

[11] A.S.Fouda, H.A.Abdul Wahed (2016) Corrosion inhibition of copper in $\mathrm{HNO}_{3}$ solution using thiophene and its derivatives. Arabian Journal of Chemistry, 9 Supplement 1, S91-S99.

[12] D.Savita, P. Mourya, N. Chaubey, V. K. Singh, M. M. Singh (2016) Eco-Friendly Inhibitors for Copper Corrosion in Nitric Acid: Experimental and Theoretical Evaluation. Metallurgical and Materials Transactions B, 47(1), 47-57.

[13] A.M. Eldesoky, Hala.M. Hassan, A.S.Fouda (2013) Studies on the Corrosion Inhibition of Copper in Nitric Acid Solution Using Some Pharmaceutical Compounds, Int. J. Electrochem. Sci., 8, 10376 10395.

[14] K.Barouni, A.Kassale, A.Albourine, O.Jbara, B. Hammouti, L. Bazzi (2014) Amino acids as corrosion inhibitors for copper in nitric acid medium: Experimental and theoretical study, J.Mater. Environ. Sci., 5(2) 456-463.

[15] M.Mihit, K. Laarej, H. Abou El Makarim, L. Bazzi, R. Salghi, B. Hammouti ( 2010) Study of the inhibition of the corrosion of copper and zinc in $\mathrm{HNO}_{3}$ solution by electrochemical technique and quantum chemical calculations, Arabian J. of Chemistry, 3(1), 55-60. 
[16] A.Chira, B.Bucur, G.Lucian Radu (2017) Electrodeposited Organic Layers Formed from Aryl Diazonium Salts for Inhibition of Copper Corrosion. Materials, 10( 3) 235-248.

[17] G.Gece (2011) Drugs: A review of promising novel corrosion inhibitors, Corros. Sci., 53(12), 3873-3898

[18] M.E.Olson (2010) Flora of North America Committee, ed. eFlora summary: Moringaceae: Drumstick Family. Flora of North America, North of Mexico. 7. New York and Oxford, 167-169.

[19] P.Muthukrishnan, B.Jeyaprabha, P. Prakash (2013) Corrosion Inhibition of Leucaena Leucocephala Pod on Mild Steel in Sulphuric Acid Solution, Acta Metall. Sin. (Engl. Lett.) 26(4) , 416 - 424.

[20] S.Chen, A.Singh, Y.Wang, W. Liu, K. Deng, Y. Lin (2017) Inhibition effect of Ilex kudingcha C.J. Tseng (Kudingcha) extract on $\mathrm{J} 55$ Steel in $3.5 \mathrm{wt} \% \mathrm{NaCl}$ Solution Saturated with $\mathrm{CO}_{2}$, Int. J. Electrochem. Sci., 12, $782-796$

[21] A.S.Fouda, S.M.Rashwan, H.E.Ibrahim, F. Salamony (2017) Corrosion Inhibition of Cu in Nitric Acid Solution using Asafoetida Extract (ASFE) as Green Inhibitor. J. Applicable Chem. 6 (1), 176189.

[22] G.A.El-Mahdy, A.M.Atta, H.A.Al-Lohedan, A.O.Ezzat (2015) Influence of Green Corrosion Inhibitor based on Chitosan Ionic Liquid on the Steel Corrodibility in Chloride Solution, Int. J. Electrochem. Sci., 10, 5812 - 5826.

[23] M.Lebrini, F.Robert, C.Roos (2011) Alkaloids Extract from Palicourea guianensis Plant as Corrosion Inhibitor for C38 Steel in $1 \mathrm{M}$ Hydrochloric Acid Medium, Int. J. Electrochem. Sci., 6, 847 - 859

[24] A.S.Fouda, Y.M.Abdallah, G.Y.Elawady, R.M. Ahmed (2014) Zygophllum coccineum L. Extract as green corrosion inhibitor for copper in $1 \mathrm{M} \mathrm{HNO}_{3}$ Solutions, Int.J. Adv. Res., 2(11) ,517-531.

[25] G.Khan, K.S.Newaz, W.J.Basirun, H.B.Mohd Ali, F. L.Faraj (2015) Application of Natural Product Extracts as Green Corrosion Inhibitors for Metals and Alloys in Acid Pickling Processes- A review, Int. J. Electrochem. Sci., 10, 6120 - 6134.

[26] G.M. Al-Senani (2016) Corrosion Inhibition of Carbon Steel in acidic chloride medium by Cucumis Sativus (cucumber) Peel Extract, Int. J. Electrochem. Sci., 11, 291 - 302.

[27] A.S.Fouda, A.Y.El-Khateeb, M.lbrahim, M.Fakih (2015) Adhatoda aqueous Plant Extract as Environmentally Benign Corrosion Inhibitor for Carbon Steel in Sanitation Water in Polluted $\mathrm{NaCl}$ Solutions and its Biological effect on Bacteria, Nature and Science 13(2),71-82.

[28] J.Aljourani, M.A.Golozar, K.Raessi( 2010) The inhibition of carbon steel corrosion in hydrochloric and sulfuric acid media using some benzimidazole derivatives, Mater. Chem. Phys.,12(1-2), 320-325.

[29] G.Gece (2008) The use of quantum chemical methods in corrosion inhibitor studies Corros. Sci., 50(11), 298-2992.

[30] L.Tang, X.Li, Y.Si, G.Mu, G.Liu (2006) The synergistic inhibition between 8-hydroxyquinoline and chloride ion for the corrosion of cold rolled steel in 0.5 M sulfuric acid, Mater. Chem. Phys., 95(1), 29-38.

[31] L.Tang, G.Mu, G.Liu (2003) The effect of neutral red on the corrosion inhibition of cold rolled steel in 1.0 M hydrochloric acid, Corros. Sci., 45(10), 22512266.

[32] S.S.Abdel-Rehim, K.F.Khalid, N.S.Abd-Elshafi (2006) Electrochemical frequency modulation as a new technique for monitoring corrosion inhibition of iron in acid media by new thiourea derivative, Electrochim. Acta, 51(16), 3269-3277.

[33] X. Li, L.Tang (2005) Synergistic inhibition between $\mathrm{OP}$ and $\mathrm{NaCl}$ on the corrosion of cold-rolled steel in phosphoric acid Mater, Chem. Phys., 90(2-3), 286297.

[34] A.A. El-Awady, B. Abd El-Nabey, S. G. Aziz (1992) Kinetic Thermodynamic and Adsorption Isotherms Analyses for the Inhibition of the Acid Corrosion of Steel by Cyclic and Open Chain Amines, Electrochem. Soc., 139(8), 2149-2154.

[35] S. S. Abd El-Rehim, H.H. Hassan, M.A. Amin (2001) Corrosion inhibition of aluminum by 1,1 (lauryl amido)propyl ammonium chloride in $\mathrm{HCl}$ solution. Mater. Chem. Phys., 70( 1), 64-72.

[36] A. K.Singh, M. A.Quraishi (2010) The effect of some bis-thiadiazole derivatives on the corrosion of mild steel in hydrochloric, Corros. Sci., 52(4) 1373-1385.

[37] F.Bentiss, C.Jama, B.Mernari, H. El Attari, L. El Kadi, M. Lebrini, M. Traisnel, M. Lagrenee (2009) Corrosion control of mild steel using 3,5-bis(4methoxyphenyl)-4-amino-1,2,4-triazole in normal hydrochloric acid medium. Corros. Sci., 51(8),16281635

[38] H.Ashassi-Sorkhabi, D.Seifzadeh, M.G.Hosseini, (2008) EN, EIS and polarization studies to evaluate the inhibition effect of $3 \mathrm{H}$-phenothiazin- 3- one, 7dimethylamin on mild steel corrosion in $1 \mathrm{M} \mathrm{HCl}$ solution, Int. J. Electrochem. Sci., 50, 3363-3370.

[39] J.W.Schultze, K.Wippermann (1987) Inhibition of electrode processes on copper by AHT in acid solutions. Electrochim. Acta. 32(5), 823-831.

[40] A.Popova, M.Christov (2006) Evaluation of impedance measurements on mild steel corrosion in acid media in the presence of heterocyclic compounds, Corros. Sci., 48(10), 3208-3221.

[41] G. Echem (2003) Analyst Manual.

[42] R.Vera, R.Schrebler, P.Cury, R. Del Rio, H. Romero (2007) Inhibition of corrosion of HSC in well water by arginine-Zn2+ system, J. Appl. Electrochem., 37, 519-525.

[43] M.S.Morad (2008) Inhibition of iron corrosion in acid solutions by Cefatrexyl: behaviour near and at the corrosion potential, Corros. Sci. 50, 436-448.

[44] S.K.Shukla, M.A.Quraishi (2010) The effects of pharmaceutically active compound doxycycline on the corrosion of mild steel in hydrochloric acid solution, Corros. Sci., 52, 314-321.

[45] R.Solmaz, G.Kardas, B.Yazici, M.Erbil (2008) Adsorption and corrosion inhibitive properties of 2amino-5-mercapto-1,3,4-thiadiazole on mild steel in hydrochloric acid media, Colloids Surf. A Physicochem. Eng. Asp., 312, 7-17. 


\section{IZVOD}

\section{EKSTRAKT BILJKE MORINGA OLEIFERA KAO INHIBITOR KOROZIJE BAKRA U MEŠAVINI BINARNE KISELINE $\left(\mathrm{HNO}_{3}+\mathrm{H}_{3} \mathrm{PO}_{4}\right)$}

Ponašanje Cu u $1 M$ mešavini azotne i fosforne kiseline, koje sadrže različite koncentracije
ekstrakta lišća moringa oleifera (MOL), proučavano je gubitkom težine (WL) i elektrohemijskim
tehnikama [potentiodinamička polarizacija (PP), elektrohemijska impedansna spektroskopija (EIS)
i elektrohemijska modulacija frekvencije (EFM)]. Utvrđeno je da je maksimalna efikasnost inhibicije
iznosila $89 \%$ pri koncentraciji od 0.300 molL ${ }^{-1}$ ekstrakta na $298 K$ nakon 3 sata potapanja.
Efikasnost inhibicije (IE) povećana je sa povećanjem koncentracije ekstrakta dok je smanjena
povećanjem temperature što ukazuje na to da se ekstrakt fizički adsorbuje na Cu površini.
Adsorpcija ekstrakta sledi Langmuirova izotermna adsorpcija. Određeni su i razmatrani određeni
termodinamički parametri procesa aktivacije i adsorpcije. Ispitana je i analizirana i površina.

Ključne reči: korozija bakra; smeša $\mathrm{HNO}_{3}+\mathrm{H}_{3} P \mathrm{O}_{4}$, ekstrakt moringa oleifera; EIS, EFM, AFM, SEM.

\section{Naučni rad}

Rad primljen: 25. 03. 2018.

Rad prihvaćen: 10. 06. 2018.

Rad je dostupan na sajtu: www.idk.org.rs/casopis

(C) 2018 Authors. Published by Engineering Society for Corrosion. This article is an open access article distributed under the terms and conditions of the Creative Commons Attribution 4.0 International license (https://creativecommons.org/licenses/by/4.0/) 